\title{
Assessing the Maturity Level of Saint Petersburg's Digital Government
}

\author{
Elena Rytova ${ }^{1}$, Tatiana Verevka ${ }^{1}$, Svetlana Gutman ${ }^{1}$, Sergey Kuznetsov ${ }^{2}$ \\ ${ }^{1}$ Peter the Great St. Petersburg Polytechnic University, Russia, 195251, St. Petersburg, Polytechnicheskaya, \\ 29 \\ ${ }^{2}$ Institute for Regional Economic Studies, Russian Academy of Sciences, Russia, 190013, St. Petersburg, \\ Serpuhovskaya, 38
}

\begin{abstract}
This paper assesses the readiness of Russia's government authorities and local governments for a digital transformation. The digital economy's condition in the public sector is analyzed, and the problems and possibilities of developing a digital economy in this area are identified. Based on an analysis of the current methods for assessing countries' readiness for a digital economy and international models to evaluate the development of an e-government, a methodological approach is developed to enable the assessment of a "digital government's" maturity level at various governmental levels. St. Petersburg was selected as the object of this paper's research. Expert procedures, methods for gathering and processing statistical information, and fuzzy logic served as the methodological basis for this paper's calculations. The maturity level of the city's digital economy was identified using a fuzzy-set approach. The results of these calculations show that, despite numerous solutions aimed at developing digitalization in the public sectors of Russia and, in particular, St. Petersburg, the maturity level of the city's digital government remains insufficient to satisfy society and businesses' modern demands. Based on the conducted research, this paper highlights the reasons for the low maturity level of St. Petersburg's digital government and develops recommendations on how to increase this maturity level.
\end{abstract}

Keywords: Digital economics; Digital government; Fuzzy logic; Smart government; St. Petersburg

\section{Introduction}

Over the past 20 years, Russia has actively become involved in digitally transforming its economy and public administration. During the first stage of these reforms, from 2003 to 2013, the "Electronic Russia 2002-2010" program was created and carried out. Throughout its run, the program emphasized the issue's technical and infrastructural sides since, at that time, technological factors held back the development of an e-government. As a result of completing this program, the transformation's technological effect was largely achieved-unlike its social-economic effect, which proved insufficient despite significant financing from the government. The program's results were impressive since it was able to create a base infrastructure for an e-government. A key step forward was the creation of the Single Public and Municipal Services Portal, gosuslugi.ru.

The Single Public Services Portal (SPSP) has been a front office for Russia's digital government since its creation in 2009, providing users with information, forms and applications, and payment services. It has undergone several changes and modernizations, adding new technologies and functionality as well as adapting to the new principle of

${ }^{*}$ Corresponding author's email: rytova_ev@spbstu.ru, Tel.: +7-921-935-18-92

doi: 10.14716/ijtech.v11i6.4440 
providing user-focused services. The number of users on the portal is growing steadily, although many potential users still use the simple registration process instead (without verifying their identity in-person), which limits the types of services available to these users. Almost 100 million users are currently registered on the portal. The percentage of Russians registered on the single portal is comparable to corresponding indicators in the United Kingdom and Australia.

In 2010, during the development of previous initiatives, the government decree "On the Government Program of Russia 'Information Society (2011-2020)'” (later extended to 2019-2024) was adopted. This program aimed to further develop one-click access to government services through the SPSP, as well as multi-functional service centers, at creating an interagency system for electronic communication and a system for managing documents, and at providing public access to information about government bodies' activities. The government's constant focus on digital transformation the highest levels of power allowed Russia to quickly rise in international ratings of e-governments and to achieve remarkable success. The number of users of online public and municipal services doubled in just one year, reaching 40 million in 2016 and 70 million by 2018. Expert evaluations have pointed to the Russian public's growing confidence in a digital government, digital participation, a sharing economy, and the use of payment cards.

In 2014-2019, the program underwent constant changes after a series of presidential decrees were passed (for example, № 601 from 2012, “On the Main Areas for Improving Public Administration") as well as "Strategies for Developing an Information Society (20172030)." Other noticeable changes occurred in the related goals and expected results: for example, the goal of reducing the digital disparity between regions disappeared and reappeared several times, and it is missing from the latest version of the document. The current version of the program was adopted in 2019, and it includes several subprograms, such as Subprogram 4- "Information Government" (Ivanova, 2020).

In 2018, the "Digital Economy in Russia" national program (national project) was adopted in parallel with the "Information Society" government program. In total, 1.6349 trillion rubles are planned to be spent to implement the project. One of the national project's goals is to create a stable and safe information and telecommunications infrastructure for the high-speed transfer, processing, and storage of large amounts of data. The program includes six federal projects, such as "Digital Public Administration" (active from November 11, 2018, to December 31, 2024).

Nevertheless, in practice, the introduction of digital governments in Russia and throughout the world has accompanied several significant problems and limitations. More often than not, these concerns relate to existing government services' failure to seek a fundamental restructuring in order to provide citizens and businesses with higher-quality public services. On the contrary, the mere digitization of individual operations and documents has taken place while preserving existing interdepartmental processes and interactions. This approach has often led to the development of complex and unusable digital platforms and low satisfaction among users. For this reason, departments have experienced an insufficient penetration of digital transformations and a lack of modern channels of communication among departments. Various incompatible departmental platforms have been created, which have likewise led to more difficulty in providing public services to citizens and businesses. Finally, the divide between efficient, digital, and interactive external government platforms and traditional, mostly manual, internal processes has persisted, which does not allow for increased efficiency. The next significant problem is a lack of communication between the various levels of government (federal, regional, and municipal), which causes imbalances in the use of digital technologies, 
depending on places' levels of government. Many local government organizations do not meet national requirements for digitalization. Another significant problem is qualified staff, as well as their training and retraining in new digital realities. At the same time, this problem concerns both management personnel and executors. This problem is essential and complex, relating to regions' quality of human capital (Kuladzhi et al., 2017; Skotarenko et al., 2019).

To control and monitor the results of eliminating these indicated problems, a tool must be developed that allows a digital government's maturity level to be evaluated and compared in a short period. In connection with this necessity, the goal of this research is to develop a methodological approach that makes assessing the maturity level of a digital government possible at different governmental levels. Evaluating a digital government's maturity at different levels allows for a gradual elimination of the imbalanced development between federal, regional, and local systems of digital government, and this evaluation can also serve as a basis for decision-making about further development in this field.

\section{Methodology}

Despite the large number of solutions and government programs that have been adopted at the highest level in order to transition into a digital government, several problems remain, which have led to an increase over past 10 years in the number of studies and developments surrounding this issue. The goals of most of the related research can be divided into two broad groups: (a) defining the theoretical foundations and main problems of a digital transformation, including the area of public administration (Petrov et al., 2016; Bataev, 2018; Bataev et al., 2018; Woodhead, 2018; Sankowska, 2018); and (b) assessing the maturity levels of a digital economy as a whole and, in particular, of digital public administration as one of digital transformation's main elements (World Bank., 2018; Mahesa et al., 2019; Sidorenko et al., 2019; Nurcahyo, R. et al., 2018).

Bataev et al. (2018) and Petrov et al. (2016) indicated the following basic problems of developing an e-government in Russia: (a) a lack of common reform strategy adopted across all three levels of power; and (b) regions' developing their own platforms. Even interdepartmental communication within one governmental level did not attain real integration-including no direct connection between digital reforms and changes to the government system itself, no priorities for openness, participation, or even quality, a sizable difference in ICT development between different regions, between rural areas and cities, and between large and small cities, et cetera. Moreover, a significant difference in achieved development stages for e-governments between various types of services and government bodies has been observed. On average, an e-government stays at the first information stage while several services are offered at the interaction stage. The lack of an effective system to monitor and evaluate an e-government's development, and extensive differences in data (in terms of format, quality, accessibility, and so on), also make interdepartmental interaction more difficult, as do gaps in the legal regulation of an e-government.

To assess readiness for a digital economy, several methods have been developed. The most famous method, at the moment, is the DECA methodology. This approach to assessing a country's readiness for a digital economy (Digital Economy Country Assessment; DECA) is designed to assess the current level of development and determine the level of maturity in a country's digital economy. The assessment helps identify the key problems and possibilities for further growth, as well as the areas that require more thorough analysis.

The next approach to assessing this readiness is the Cisco Global Digital Readiness Index, developed jointly by Cisco and Gartner (Cisco, 2020). This index was calculated for 141 countries, based on seven components (factors and sub-indicators), reflecting levels of 
basic societal needs, ease of doing business, technology infrastructure, technological adoption in society, start-up environment, human capital, and business and government investments. These seven components were chosen to reflect countries' levels of readiness for digital technology and to understand the key activities and investments necessary for a country to increase its digital readiness. To obtain a general integral indicator of digital readiness, these factors were standardized and added together.

Another international index, the Networked Readiness Index (NRI), created by the World Economic Forum, is also a widely used tool for assessing how much of the necessary drivers for revealing ICT potential a country possesses and whether digitalization actually affects the country's economy and society. The NRI combines 53 indicators, which are consolidated into four index subgroups.

Next, we examine the international approaches to assessing an e-government's development. The most widely used index is the E-Government Development Index (EGDI) (E-Government Survey 2020 Digital Government in the Decade of Action for Sustainable Development With Addendum on COVID-19 Response, n.d.). The EGDI is a composite indicator of three "measurements" of e-government, expressed by the subindices online service index (OSI), telecommunication index, ICT coverage (TII), human capital index, and opportunities to master ICT (HCI). The EGDI assesses not only electronic services on their own but also considers how a country uses ICT and the extent of the population's involvement. OSI assesses a government's digital presence and its readiness to provide services and interact with citizens or businesses digitally. The TII assesses the existing infrastructure that is necessary for citizens to participate in the work of an e-government. The HCI assesses citizens' ability to use e-government services, as well as the literacy rate and gross enrollment rate in primary, secondary, and higher education.

Mahesa, Yudoko, and Anggoro from the School of Business and Management, Bandung Institute of Technology, Indonesia, proposed an approach to assessing the digitalization of smart cities and regions (Mahesa et al., 2019). Their methodology for assessing regional (or urban) readiness for digitalization comprises two stages. At the first stage, regions (or cities) are assessed according to three main elements: structure, including human capital, financial capital, and management capital; infrastructure, including physical, digital, and social; and superstructures, including regional regulation, institutional development, and development based on various aspects of the "smart city" concept. At the second stage, regions (or cities) are additionally assessed based on the measurements of the six indicators of a smart city: smart government, smart branding, smart economy, quality of life, smart society, and smart environment. Each measurement is assessed using a set of qualitative indicators. Only two rating options exist for each indicator: available and unavailable. Thus, for each indicator, a maximum of one point can be given. In total, 74 indicators are used; therefore, the maximum rating for a region or city is 74 . Government quality (GQ) is assessed using the 16 indicators. With the help of survey tables, expert data for each indicator and a composite expert evaluation of a region's (or city's) readiness can be obtained.

The work of Di Maio, Howard, and Archer provides a visualization of the five stages of transitioning to a digital government as a transition from the initial stage of an egovernment to an open government and then to a data-centric government, which then develops into a fully digital government and, finally, becomes a smart government.

In the work Sidorenko et al. (2019), the authors offer their own method for assessing the effectiveness of digitalizing the public sector as a multi-factor toolkit: assessing the technological feasibility of digital solutions for government systems, assessing the infrastructure readiness for digitalization, assessing the economic soundness of 
introducing digital services into the public sector, and assessing the subjective parameters of digitalization. For each of these groups of assessments, aggregated indicators were developed, along with the assessment criteria for each indicator. A distinct method of data collection and processing is used for each criterion: statistical analysis, expert evaluation, opinion polls, and mathematical and forecasting methods. Most of the indicators presented correlate with international and foreign models of measuring a digital economy. At the same time, no aggregation of the set of indicators used and the calculations for the integral ratings occurs.

Thus, all systems for assessing a digital government's maturity level highlight four main aspects that must be evaluated:

1. Infrastructure, including broadband internet coverage.

2. The human factor, including the development level of human capital in a territory and people's involvement in digital government systems.

3. Digital government systems' functional qualities.

4. Socio-economic factors pertaining to the public sector's digitalization: interactions between businesses and governments and the level of innovation development.

At the same time, no hybrid systems exist that could simultaneously consider the objective information reflected in statistical indicators and expert information in any aspects that are poorly assessed using quantitative methods. In connection with this limitation, this paper suggests using fuzzy logic whose application enables the elimination of these indicated disadvantages and an integral rating of the readiness for a digital government in a region (or city), in terms of digitalization.

The methods used to achieve this study's goals can be systematic, comparative, and content-analyzing, belonging to the qualitative methods category. Methods of gathering and processing statistical information, expert procedures, and fuzzy logic served as the methodological basis for this article's calculations (Zadeh, 1965).

The sequence of steps for achieving our research goal is:

1. Determine the makeup and quantitative as well as qualitative indicators that characterize the readiness level for a digital government in a region (or city).

2. Introduce a linguistic variable and create a scale for assessing the readiness level for a digital government in a region (or city).

3. Standardize the indicators and create a matrix of factor values.

4. Calculate the aggregate indicator.

\section{Results and Discussion}

St. Petersburg was chosen as the object of our research. The government bodies of St. Petersburg differ slightly in their principle of operation from governments in other regions of Russia. When comparing city authorities' digitalization results with other regions of Russia, the situation in St. Petersburg can appear better. However, if comparing the achievements of St. Petersburg authorities with Moscow authorities', then the results appear quite modest. The St. Petersburg government has planned efforts to increase government efficiency by introducing digital technologies through the "Digital Economy" government project.

To determine the maturity level of St. Petersburg's digital government, a fuzzy set approach was used. The idea of this approach is that the variables that are part of the analytical description of a model can take on linguistic values. 
The linguistic variable "maturity level of a digital government" was introduced with a description of its totality of indicators.

$$
Y=[x ; T ; D]
$$

where: $x$ is the variable name "maturity level of a digital government"; $T$ is the set of values "initial stage of an e-government," "open government," "data-centric government," "fully digital government," and "smart government"; and $D$ is the domain on the segment $[0 ; 1]$.

Each of these factors has its own domain. According to the fundamental conditions of the fuzzy set theory, if each factor is assigned the degree of its belonging to the fuzzy set $A$, then this membership is expressed by the number $\mu A(x)$-the membership function at interval $[0 ; 1]$. Thus, the value of function $Y$ will characterize the maturity level of a region's digital government, depending on several selected factors. To assess a digital government's maturity level, a scale of fuzzy values of the variable $Y$ was developed (Table 1).

Table 1 Scale of fuzzy values of the variable $Y$

\begin{tabular}{|c|c|c|}
\hline Value Set & Name & Description \\
\hline $0-0.333$ & $\begin{array}{l}\text { "initial stage } \\
\text { of e- } \\
\text { government" }\end{array}$ & $\begin{array}{l}\text { Maturity level-initial; value focus-compliance with demands, } \\
\text { efficiency; channel strategy - portal; key metrics-percentage of } \\
\text { online services. }\end{array}$ \\
\hline $0.167-0.5$ & $\begin{array}{l}\text { "open } \\
\text { government" }\end{array}$ & $\begin{array}{l}\text { Maturity level—developing; value focus-transparency and openness; } \\
\text { channel strategy—government as a platform; key metrics - percentage } \\
\text { of open data. }\end{array}$ \\
\hline $0.333-0.667$ & $\begin{array}{l}\text { "data-centric } \\
\text { government" }\end{array}$ & $\begin{array}{l}\text { Maturity level-defined; value focus-constituent value; channel } \\
\text { strategy—nongovernment channels; key metrics—numbered data- } \\
\text { driven services. }\end{array}$ \\
\hline $0.5-0.833$ & $\begin{array}{l}\text { "digital } \\
\text { government" }\end{array}$ & $\begin{array}{l}\text { Maturity level-managed; value focus-transformation; channel } \\
\text { strategy-truly multichannel; key metrics-percentage of data } \\
\text { achieved from Internet-of-Things }\end{array}$ \\
\hline $0.667-1$ & $\begin{array}{l}\text { "smart } \\
\text { government" }\end{array}$ & $\begin{array}{l}\text { Maturity level—optimizing; value focus—sustainability; channel } \\
\text { strategy-automation replaces portals; key metrics—-percentage of } \\
\text { decrease of services. }\end{array}$ \\
\hline
\end{tabular}

The factors used as inputs for modeling are presented below. Using these factors makes assessing a digital government's maturity level possible.

- X1: Human development index-an integral indicator calculated as one of the main characteristics of human potential in the studied territory.

- X2: Households with broadband internet access in the federal subjects of Russia, as a percentage of the total number of households. This indicator shows the level of telecommunications technology development in the studied territory and the digital culture's maturity level.

- X3: The portion of the population interacting with government bodies and local government via the internet (using official websites and portals of government and municipal services, mobile devices, email, and self-service terminals), as a percentage of the total population.

- X4: The portion of the population interacting with government bodies and local government via Multi-Functional Centers, as a percentage of the total population. 
- X5: The portion of the population completely satisfied with the quality of government and municipal services provided online in the federal subjects of Russia, surveyed as a percentage of the total population who use the internet to receive government and municipal services.

- X6: The portion of authorities connected to a single electronic document management system (EDMS) in the region, as a percentage. This indicator reflects the condition of the government's digital transformation and should equal $100 \%$.

- X7: The portion of requests for government services made in electronic form from the total number of requests for government services, as a percentage. This indicator is one of the key indicators in determining a digital government's maturity level.

- X8: Expenditures on technological innovations as a percentage of the total amount of shipped goods, completed work and rendered services expressed as a percentage. This indicator is the most important when transitioning to a digital economy since innovations are what open opportunities for a digital economy's growth.

Table 2 Input values of model indicators for 2018 (Grigoriev, n.d.; Federal Service of Government Statistics, 2019)

\begin{tabular}{lrrrrrrrr}
\hline \multicolumn{1}{c}{ Indicators } & $\mathrm{X} 1$ & $\mathrm{X} 2$ & $\mathrm{X} 3$ & $\mathrm{X} 4$ & $\mathrm{X} 5$ & $\mathrm{X} 6$ & $\mathrm{X} 7$ & $\mathrm{X} 8$ \\
\hline St. Petersburg & 0.945 & 84.7 & 40.9 & 15.7 & 66.1 & 81 & 72.5 & 2.5 \\
\hline Russia, average value & 0.89 & 73.2 & 54.5 & 19.6 & 73.2 & $100^{*}$ & $70^{*}$ & 2.1 \\
\hline $\begin{array}{l}\text { Standard value for St. } \\
\text { Petersburg }\end{array}$ & 0.062 & 0.157 & -0.250 & -0.199 & -0.097 & -0.190 & 0.036 & 0.190 \\
\hline
\end{tabular}

${ }^{*}$ Estimated values for the government authorities were used, not the average values for Russia

The values of the chosen factors were standardized according to the following formula:

$$
\mathrm{x}=\frac{\mathrm{x}_{\mathrm{i}}-\overline{\mathrm{x}}}{\overline{\mathrm{x}}}
$$

In this model, the significance levels of all factors are taken equal. The authors selected eight factors for analysis, suggesting that the significance of the factors $r_{i}$ is calculated according to the formula: $r_{i}=\frac{1}{8}$. In other words, the level of significance for each factor with their total number equal to 8 is 0.125 .

According to Nedosekin (2003), if there is a set of $I=1 . . N$ separate factors with their current values $x i$, and each factor is assigned its own $M$-level classifier, then the quantitative value of an aggregated factor can be determined according to the double convolution formula:

$$
\mathrm{A}_{\mathrm{N}}=\sum_{\mathrm{j}=1}^{\mathrm{M}} \alpha_{\mathrm{j}} \sum_{\mathrm{i}=1}^{\mathrm{N}} \mathrm{d}_{\mathrm{i}} \mu_{\mathrm{ij}}\left(\mathrm{x}_{\mathrm{i}}\right)
$$

where $\alpha_{j}$-are the nodal points, $d_{i}-$ is the weight of the $i$ factor in the convolution, $\mu_{i j}\left(x_{i}\right)-i s$ the membership function of the $j$ qualitative level relative to the current value of the $i$ factor, and $M$ - is the number of levels of the classifier.

According to the obtained data, the value of the integral indicator for a digital government's maturity in 2018 equaled 0.53 , which means this indicator belongs $81 \%$ to the subset "data-centric government" and only 19\% to "digital government." This finding means that, despite the fairly high (for Russia) results of implementing programs for developing a digital government, the programs' goals have yet to be fully reached. A low value is observed for several indicators, which can be classified as "below average." This 
result cannot be considered satisfactory-although St. Petersburg is positioned by many researchers and government representatives as a "smart" city (Bataev et al., 2018; Galkin et al., 2018; Ivanova, 2020).

Several problems may be the reason for St. Petersburg's low ratings in its digital government's maturity level, which we will now address.

Unfortunately, executive authorities' work in St. Petersburg cannot be completed efficiently and promptly due to the city's poorly functioning interdepartmental communication and an incomplete understanding of the areas of responsibility for each executive authority in St. Petersburg. Currently, the following problems exist in government authorities' work in St. Petersburg:

- A low proficiency level in technology and computers among government agency employees.

- Insufficient allocation of budget funds to train employees and purchase technology and equipment.

- Poor work among government servers and an insufficient preparedness for large flows of users.

Eliminating these disadvantages could have a significant impact on the condition of the researched problem and increase the assessed maturity of St. Petersburg's digital government.

This paper considers only 2018 data for St. Petersburg. This focus makes studying the dynamics of e-government development and identifying existing trends impossible. This limitation is due to problems with the data required for such an assessment. However, in a future investigation, we plan to collect information and assess dynamics not only in St. Petersburg but also in other regions of the Russian Federation for comparative analysis.

\section{Conclusions}

A digital government is based on previous e-government reforms. It aims to improve government services using the new opportunities provided by digital technologyenabling a government to better serve its citizens and creating a favorable environment for business and industry competition.

Russia has reached some impressive achievements in creating a reliable national broadband infrastructure, providing-among other achievements-a widespread penetration of mobile communication. Several initial steps have also been made in establishing the interdepartmental cooperation necessary for providing digital services through a single national portal.

In terms of transitioning to the next digital transformation stage, Russia's main achievement has been its development of a modernized digital infrastructure that is capable of supporting the "government as a platform" approach.

The transition to data-driven administration and the innovative use of new digital technologies - such as data analytics and the blockchain (Babkin et al., 2018), artificial intelligence, and the Internet-of-Things-has sped up the transition to a new level of digital government in Russia. This transition can particularly create the basis for future technological breakthroughs (Berawi, 2019a; Berawi, 2019b).

Achieving a leading position in digital government entails a complete internal digital transformation of the public sector, as well as providing individual services to citizens and businesses via several trustworthy, transparent, and efficient channels. To accomplish these goals, a significant transformation of Russia's existing e-government architecture is required. This architectural transformation must include the 
reengineering of administrative processes and an emphasis on using national databases, the joint use of digital services among government bodies, and the provision of active services on the digital government platform to allow direct interaction with citizens and businesses. Only by rearranging the digitalization processes in all areas discussed above can the government transition to the fifth maturity level- "smart government".

\section{Acknowledgements}

This research work was supported by the Academic Excellence Project 5-100 proposed by Peter the Great St. Petersburg Polytechnic University.

\section{References}

Babkin, A.V., Burkaltseva, D.D., Betskov, A.V., Kilyaskhanov, H.S., Tyulin, A.S., Kurianova, I.V., 2018. Automation Digitalization Blockchain: Trends and Implementation Problems. International Journal of Engineering and Technology (UAE), Volume 7(14), pp. 1-10

Bataev, A.V., 2018. Analysis and Development the Digital Economy in the World. In: Proceedings of the $31^{\text {st }}$ International Business Information Management Association Conference (IBIMA), pp. 1-10

Bataev, A.V., Gorovoy, A.A., Mottaeva, A., 2018. Evaluation of the Future Development of the Digital Economy in Russia. In: Proceedings of the $32^{\text {nd }}$ International Business Information Management Association Conference (IBIMA), pp. 1-10

Berawi, M.A., 2019a. Managing Nature 5.0 in Industrial Revolution 4.0 and Society 5.0 Era. International Journal of Technology, Volume 10(2), pp. 222-225

Berawi, M.A., 2019b. The Role of Industry 4.0 in Achieving Sustainable Development Goals. International Journal of Technology, Volume 10(4), pp. 644-647

Cisco, 2020. Cisco Global Digital Readiness Index 2019. Available Online at: https://www.cisco.com/c/dam/en_us/about/csr/reports/global-digital-readinessindex.pdf, Accessed on October, 2020

Federal Service of Government Statistics, 2019. Information Society in Russia. 2019: Statistical Collection, NRI HSE (Ed.).; National Research Institute "Higher School of Economics." Office of Federal Service of Government Statistics, Tsentrosoyuz building, Moscow, Russia

Galkin, A.A., Lesniak, Y.S., Virabyan, S.O., 2018. Bazovye Napravleniye Razvitiya Tsifrovoy Ekonomiki Rossiyskoy Federatsii (The Basic Directions of the Development of the Digital Economy of the Russian Federation). Gosudarstvennoye i Munitsipal'noye Upravleniye., Volume 1, pp. 1-6

Ivanova, M.V., 2020. Systemy Otsenki Tsifrovoy Transformatsii Gosudarstvennogo Upravleniya: Sravnitel'nyy Analiz Rossiyskoy i Zarubezhnoy Praktiki. Government Administration. E-Newsletter, Issue 79

Kuladzhi, T.V., Babkin, A.V., Murtazaev, S.A.Y., 2017. Enhancing Personnel Training for the Industrial and Economic Complex in the Conditions of the Digital Economy. In: Proceedings of 2017 IEEE 6 $^{\text {th }}$ Forum Strategic Partnership of Universities and Enterprises of Hi-Tech Branches (Science, Education, Innovations.), pp. 1-4

Mahesa, R., Yudoko, G., Anggoro, Y., 2019. Dataset on the Sustainable Smart City Development in Indonesia. Data in Brief, Volume 25, pp. 1-16

Nurcahyo, R., Wibowo, A.D., Putra, R.F.E., 2018. Key Performance Indicators Development for Government Agency. International Journal of Technology, Volume 6(5), pp. 856-863

Nedosekin, A., 2003. Nechetkiy Finansovyy Menedzhment (Fuzzy Financial Management). Moscow, Russia: AFA Library 
Petrov, O.V, Bunchuk, M., Stott, A.C., Hohlov, Y., 2016. Digital Government 2020: Prospects for Russia. Washington, D.C.: World Bank Group, Available Online at http://documents.worldbank.org/curated/en/562371467117654718/Digitalgovernment-2020-prospects-for-Russia, Accessed October 5, 2020

Sankowska, P., 2018. Smart Government: An European Approach toward Building Sustainable and Secure Cities of Tomorrow. International Journal of Technology, Volume 9(7), pp. 1355-1364

Sidorenko, E.L., Bartsits, I.N., Khisamova, Z.I., 2019. The Efficiency of Digital Public Administration Assessing: Theoretical and Applied Aspects. Public Administration Issues, Volume 2, pp. 93-114

Skotarenko, O., Babkin, A., Senetskaya, L., Bespalova, S., 2019. Tools for Digitalization of Economic Processes for Supporting Management Decision-Making in the Region. In: IOP Conference Series: Earth and Environmental Science, Volume 302(1), pp. 1-8

The World Bank, 2018. Competing in the Digital Age: Russia Digital Economy Report. Washington, D.C. : World Bank Group. Available online at http://documents1.worldbank.org/curated/en/860291539115402187/pdf/Competi ng-in-the-Digital-Age-Policy-Implications-for-the-Russian-Federation-Russia-DigitalEconomy-Report.pdf, Accessed October 5, 2020

Woodhead, R., 2018. Building a Smarter City. International Journal of Technology, Volume 9(7), pp. 1509-1517

Zadeh, L.A., 1965. Fuzzy Sets-Information and Control-1965. Information and Control, Volume 8(3), pp. 338-353 